CENTRE for ECONOMIC

$P$ E R F O R M A N C E

CEP Discussion Paper No 846

January 2008

\title{
On the Extent of Re-Entitlement Effects in Unemployment Compensation
}

Javier Ortega and Laurence Rioux 


\begin{abstract}
A dynamic labor matching economy is presented, in which the unemployed are either entitled to unemployment insurance (UI) or unemployment assistance (UA), and the employees are either eligible for UI or UA upon future separations. Eligibility for UI requires a minimum duration of contributions and UI benefits are then paid for a limited duration. Workers are risk-averse and wages are determined in a bilateral Nash bargain. As eligibility for UI does not automatically follow from employment, the two types of unemployed workers have different threat points, which delivers equilibrium wage dispersion. Most of the variables and parameters of the model are estimated using the French sample of the European Community Household Panel (1994-2000). We show that extending the UI entitlement improves the situation of all groups of workers and slightly lowers unemployment, while raising UI benefits harms the unemployed on assistance and raises unemployment. Easier eligibility fo $\mathrm{r}$ UI also improves the situation of all groups of workers and favors relatively more the least well-off than longer entitlement. The re-entitlement effect in France lowers by $10 \%$ the rise in the wage and by $13 \%$ the rise in unemployment following a $10 \%$ increase in benefit levels.
\end{abstract}

Keywords: re-entitlement effects, unemployment compensation, matching.

JEL Classifications: J41, J65.

Data: ECHP

This paper was produced as part of the Centre's Labour Markets Programme. The Centre for Economic Performance is financed by the Economic and Social Research Council.

\title{
Acknowledgements
}

A previous version of this paper circulated under the title "The interplay between insurance and assistance in unemployment compensation systems". We would like to thank Yann Algan, Pierre Cahuc, Fabrice Collard, Martial Dupaigne, Patrick Fève, José-Enrique Galdón, Thierry Kamionka, Francis Kramarz, Stéfan Lollivier, Alan Manning, Dirk Niepelt, Barbara Petrongolo, Chris Pissarides, Bruno Van der Linden, and seminar participants at THEMA (Cergy-Pontoise), JMA, T2M, EALE, Universitat Pompeu Fabra, Toulouse Seminar on Macroeconomics, CEPR DAEUP, and IZA for their comments.

Javier Ortega is a Research Economist at the Centre for Economic Performance, London School of Economics. He is also affiliated to CEPR, FEDEA, and IZA. Laurence Rioux is a Research Economist at the Centre de Recherche en Économie et Statistique (CREST). He is also affiliated to the Toulouse School of Economics, CEPR, FEDEA, and IZA

Published by

Centre for Economic Performance

London School of Economics and Political Science

Houghton Street

London WC2A 2AE

All rights reserved. No part of this publication may be reproduced, stored in a retrieval system or transmitted in any form or by any means without the prior permission in writing of the publisher nor be issued to the public or circulated in any form other than that in which it is published.

Requests for permission to reproduce any article or part of the Working Paper should be sent to the editor at the above address.

(C) J. Ortega and L. Rioux, submitted 2007

ISBN 978-0-85328-221-1 


\section{Introduction}

The characteristics of unemployment compensation systems have increasingly attracted attention, beyond the interest in the level of unemployment insurance (UI) benefits alone. ${ }^{1}$ One important strand of this recent literature has revisited "re-entitlement effects" identified by Mortensen (1977) as a counteracting force to the standard disincentive effect of UI on job acceptance. In Mortensen (1977), taking a job opens the door to UI entitlement upon future job loss, and thus more generous UI makes current employment more attractive in the first place. Recently, Fredriksson and Holmlund (2001), Albrecht and Vroman (2005) and Coles and Masters (2006) show that re-entitlement effects remain valid in models where both the arrival rate of job offers and the distribution of wage offers are endogenous.

This article provides a quantification of re-entitlement effects in markets with search frictions, and studies the macroeconomic and redistributive impact of potential reforms to modern unemployment compensation system. These effects are more easily identified for Europe, where UI benefit levels and benefit durations are generous. One data set, the European Community Household Panel (ECHP), provides all the information necessary to quantify re-entitlement effects for the 15 pre-enlargement members of the European Union between 1994 and 2000. Among these countries, we focus on France mostly because the French unemployment compensation system is one of the very few that remained unchanged in this period.

The contribution of this work to the existing literature is twofold. First, we model the French unemployment compensation system remaining as close as possible to its actual institutional features, namely the availability of insurance (UI) and assistance (UA) benefits, the limited duration of insurance benefits, the eligibility requirements for insurance benefits, and the financing of each system - most of these features being common to the fifteen pre-enlargement members of the European Union. While the coexistence of two types of benefits is now largely accounted for, ${ }^{2}$ the existence of a minimum duration of employee contributions for eligibility for insurance benefits has not yet been modelled. By explicitly modelling non-automatic eligibility, we allow the wages of employees eligible for UI and for UA to differ in equilibrium and to move in opposite directions after changes in the environment. We believe this to be an important feature of the model, since re-entitlement effects are likely to have a differential impact on the unemployed depending on their UI eligibility status. Moreover, in the existing literature, unemployment compensation financing is either assumed away or modelled using only one tax and thus one budget constraint. In this paper we explicitly model the budget constraint of each unemployment compensation system, the UI system being financed out of social contributions on wages and the UA system through a tax on all incomes.

Second, our simulations are based on the estimates of the parameters of interest, using the 19942000 waves of the French sample of the European Community Household Panel (ECHP). Some

\footnotetext{
${ }^{1}$ See for example, Hopenhayn and Nicolini (1997), Wang and Williamson (2002), Cahuc and Malherbet (2004), Pellizzari (2006), Lentz (2007), and Pavoni (2007).

${ }^{2}$ See Cahuc and Lehmann (2000), Fredriksson and Holmlund (2001), Albrecht and Vroman (2005) and Coles and Masters (2006).
} 
existing studies provide calibrations of re-entitlement effects whenever analytical results cannot be obtained, ${ }^{3}$ but parameter values are taken from different sources and sample periods. For example, Fredriksson and Holmlund (2001) use parameter values provided by Wang and Williamson (1996), the OECD (1997), and Layard, Nickell, and Jackman (1991), some estimated on 1983-1996 and the others on 1984-1989. In contrast, our parameters are estimated on the same individuals and on the same sample period. Specifically, the ECHP has the advantage of providing all the information necessary to construct the monthly series of UI eligibility for both the employed and the unemployed, together with the benefit level received by the unemployed. This information allows us to estimate the transition rates across alternative labor market states, and the earnings associated to each state, which are then used to calibrate our theoretical model.

In our analysis we consider a labor market matching model, in which the unemployed are either entitled to UI benefits or to lower UA benefits, and the employees are either eligible for UI or UA upon separation. UI recipients face some probability of losing eligibility and start receiving UA benefits, and similarly employees eligible for UA face some probability of gaining UI eligilibity while employed. Firms open job vacancies, taking into account the average compensation received by the unemployed, and the meetings between employers and job-seekers are described by a standard matching function à la Pissarides (2000), with constant returns to scale. If an unemployed worker finds a job while currently on UI, she is still eligible for UI upon future separation, while a UA recipient finding a job is initially only entitled to UA upon separation. Individuals are assumed to be risk-averse and the budget constraint of each unemployment compensation system is explicitly modelled. Finally, wages are determined through Nash bargaining within each firm-worker pair.

We first characterize the equilibrium of this economy. As eligibility for UI does not automatically follow from employment, the two types of unemployed have different threat points, which generates equilibrium wage dispersion. Moreover, this feature of the model allows the wages of the two types of employees to move in opposite directions after a change in the unemployment compensation system. This is precisely what happens after, say, a 10\% rise in the UI benefit level. Unsurprisingly, the wage of employees eligible for UI increases, due to their improved threat point. At the same time, employees eligible for UA are willing to take a wage cut of $2.62 \%$, since more generous UI benefits makes employment relatively more attractive for them. This finding corroborates Mortensen (1977)'s result in a general equilibrium model, establishing that the re-entitlement effect dominates the disincentive effect (only) for the individuals not eligible for UI.

We show that alternative partial reforms making the unemployment compensation system more generous have contrasting impacts. In particular, extending UI entitlement by 3 months improves the utility of all groups of workers, slightly lowers unemployment, and increases output, while raising unemployment benefits by $10 \%$ makes the unemployed on UA worse-off, increases unemployment and reduces output. Furthermore, an extension of UI entitlement raises workers' welfare to a much larger extent than a rise in the UI benefit level that would generate the same ex ante additional cost to the unemployment compensation system. We further find that easier UI eligibility slightly

\footnotetext{
${ }^{3}$ Analytical results are derived when workers are risk-neutral (Albrecht and Vroman, 2005, Coles and Masters, 2006) or when there is no discounting (Fredriksson and Holmlund, 2001), while simulations are used in the more general case.
} 
reduces unemployment because this makes employment more attractive for UA recipients and thus reinforces the re-entitlement effect. Similarly as for the entitlement extension, this reform improves the situation of all the groups of workers, but relatively more that of worse-off individuals (UA recipients and employees not eligible for UI benefits). The only common feature of these three ways of making UI more generous is thus an improvement in average worker welfare and a reduction in firm profits.

Finally, we quantify re-entitlement effects. For this purpose, our model needs to be compared to a benchmark model identical in every respect except for the existence of re-entitlement effects. This model is simply the standard Pissarides (2000, ch.1) model, which is calibrated using parameters as close as possible to those of our model. ${ }^{4}$ To assess the extent of entitlement effects, we then compare the impact of a $10 \%$ increase in benefit levels in our model and in the calibrated version of Pissarides (2000). The re-entitlement effect is shown to be significant, as it reduces the wage impact of the policy by $10 \%$, and the unemployment effect by $13 \%$.

The paper is organized as follows. Section 2 describes our model. Section 3 presents the data and the method implemented to estimate the key variables and parameters of the model. In section 4 we simulate the impact of four partial reforms making the French unemployment compensation system more generous. Section 5 quantifies re-entitlement effects. Finally section 6 concludes.

\section{The model}

\subsection{Environment}

The economy consists of a fixed number of workers normalised to 1, and an endogenous number of one-job firms. Time is continuous and lasts forever. The entire analysis is carried out in steady state. Two unemployment benefit systems coexist: unemployment insurance (UI) and unemployment assistance (UA). As in the French institutional setting and unlike in the existing literature, eligibility for UI requires a "long enough" previous employment spell and lasts only for a limited period of time. $u_{1}$ unemployed individuals (also called here the "type- 1 unemployed") are entitled to UI benefits, while the remainder $u_{2}=u-u_{1}$ unemployed receive UA benefits, where $u$ denotes total unemployment. Similarly, $e_{1}$ employees are eligible for unemployment insurance in case of job loss, while the remainder $e_{2}=e-e_{1}$ would receive UA benefits, where $e$ denotes total employment. In order to keep things simple, transitions between states are here modelled as Poisson rates. We thus assume that an employed worker not entitled to UI gains eligibility at Poisson rate $p$ and that a UI recipient exhausts benefits with probability $d^{5}$ (see Figure 1). The eligibility rules of the UI system are thus fully represented by $p$ and $d$.

Firms post vacancies and transitions into employment are endogenously determined by a CRS matching function à la Pissarides (2000). Empirically, the unemployed entitled to UA have a transition rate into employment lower than the transition rate of the unemployed entitled to UI.

\footnotetext{
${ }^{4}$ We impose the values used in our calibration for those parameters common to both models and set the remaining parameters so as to match the ex post weighted averages obtained in our model.

${ }^{5}$ Fredriksson and Holmlund (2001) and Albrecht and Vroman (2005) also assume that the termination of benefits occurs at a Poisson rate. This assumption allows to keep the model stationary and is not restrictive.
} 
We model this difference in transition rates by assuming that the (exogenous) search intensity of the type-1 unemployed (normalized to 1 ) is larger than the search intensity of the type- 2 unemployed (given by $\lambda \leq 1$ ). This may reflect the effect of discouragement, lower labor market attachment or loss of social contacts that supposedly happens at relatively long unemployment durations (see e.g. Barron and Mellow, 1979, or Schmitt and Wadsworth, 1993). Meetings between individuals and firms are then ruled by:

$$
m=A m\left(v, u_{e}\right)
$$

where $m$ is the number of job matches, $v$ the number of vacancies, $u_{e} \equiv u_{1}+\lambda u_{2}$ is the number of unemployed in efficiency units, and $A$ is a scale factor. ${ }^{6}$ Given CRS and the standard random matching assumption, a vacancy is matched to a worker at Poisson rate $A q(\theta)$ where $q(\theta) \equiv \frac{m\left(v, u_{e}\right)}{v}=m\left(1, \frac{1}{\theta}\right)$, with $\theta \equiv \frac{v}{u_{e}}$ denoting labor market tightness. Similarly, a type-1 unemployed worker and a type-2 unemployed worker are matched to a vacancy respectively at rates $A \theta q(\theta)$ and $\lambda A \theta q(\theta)$.

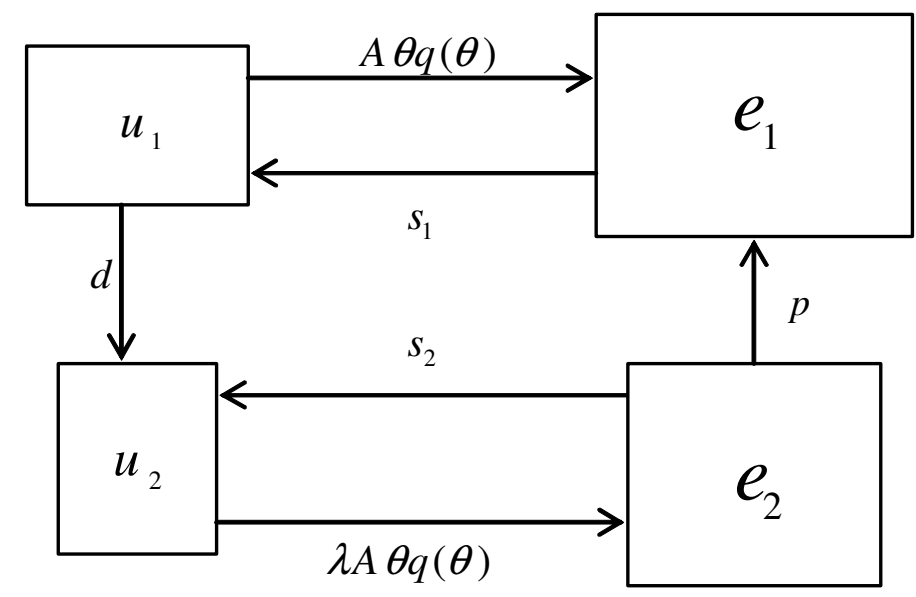

Figure 1: Labor Market Flows

In France, an unemployed worker entitled to UI who finds a job would still be eligible after a future job loss. ${ }^{7}$ For this reason, in our model, a type-1 unemployed worker finding a job becomes a type-1 employee. In contrast, a UA recipient finding a job does not initially meet the eligibility requirements, and thus becomes a type- 2 employee. Finally, employed workers eligible for UI (respectively not eligible) lose their job at an exogenous rate $s_{1}$ (respectively $s_{2}$ ). Empirically, we expect $s_{1}<s_{2}$ to automatically hold, as UI entitlement requires long enough employment spells and this precisely defines type- 1 employment. ${ }^{8}$

\footnotetext{
${ }^{6}$ This scale factor is useful for avoiding an unrealistically large cost of opening a vacancy in the simulations.

${ }^{7}$ This is explained in more details in section 3 .

${ }^{8}$ The empirical evidence in the next section shows that in average UI-eligible workers are less likely to lose their job than the non eligible, because most UI-eligible workers hold a permanent contract, which is not the case for the non eligible.
} 
The dynamic equations governing the model thus are:

$$
\begin{aligned}
& \dot{u}_{1}=s_{1} e_{1}-d u_{1}-A \theta q(\theta) u_{1}, \\
& \dot{u}_{2}=s_{2} e_{2}+d u_{1}-\lambda A \theta q(\theta) u_{2}, \\
& \dot{e}_{1}=A \theta q(\theta) u_{1}-s_{1} e_{1}+p e_{2} .
\end{aligned}
$$

The steady-state equilibrium number of individuals in each state is obtained by imposing $\dot{e}_{1}=\dot{u}_{2}=$ $\dot{u}_{1}=0$ in (2), (3), and (4). After some substitutions, we obtain:

$$
\begin{aligned}
u_{1} & =\frac{p s_{1} \lambda A \theta q(\theta)}{\Omega(\theta)} \\
u_{2} & =\frac{d s_{1}\left(s_{2}+p\right)}{\Omega(\theta)} \\
e_{1} & =\frac{p \lambda A \theta q(\theta)[d+A \theta q(\theta)]}{\Omega(\theta)}
\end{aligned}
$$

where $\Omega(\theta) \equiv d s_{1}\left[s_{2}+p+\lambda A \theta q(\theta)\right]+p \lambda A \theta q(\theta)\left[s_{1}+d+A \theta q(\theta)\right]$.

Finally, the fiscal environment is given by the financing rules of each of the two unemployment benefit systems. Let $b_{i}$ denote type- $i$ unemployment benefit and $\tau_{i}$ the tax (rate) financing type- $i$ unemployment benefit $(i=1,2)$. To keep close to the French case, the UI system is assumed to be financed out of proportional social contributions on wages, which means that the unemployed do not contribute. The budget constraint of the UI benefit system then satisfies:

$$
b_{1} u_{1}=\tau_{1}\left(w_{1} e_{1}+w_{2} e_{2}\right),
$$

i.e. the total amount of benefits $b_{1} u_{1}$ is financed through a proportional tax $\tau_{1}$ on wage income $w_{1} e_{1}+w_{2} e_{2}$. Using (5), (6), and (7), this constraint can be written as:

$$
\tau_{1}=\frac{b_{1} p s_{1}}{w_{1} p(d+A \theta q(\theta))+w_{2} d s_{1}} .
$$

Again, as in the French institutional setting, the UA system is financed through a tax $\tau_{2}$ levied on all incomes except the UA benefit itself. This tax is assumed to be proportional here. The budget constraint of the UA benefit system thus satisfies:

$$
b_{2} u_{2}=\tau_{2}\left(w_{1} e_{1}+w_{2} e_{2}+b_{1} u_{1}\right)
$$

From (5), (6), (7), and $e_{2}=1-e_{1}-u_{1}-u_{2}$, this constraint can be written as:

$$
\tau_{2}=\frac{b_{2} d s_{1}\left(s_{2}+p\right)}{w_{1} p \lambda A \theta q(\theta)[d+A \theta q(\theta)]+w_{2} d s_{1} \lambda A \theta q(\theta)+b_{1} p s_{1} \lambda A \theta q(\theta)} .
$$

\section{$2.2 \quad$ Firms}

Firms post vacancies, which are filled at rate $A q(\theta)$. Let $\gamma$ be the flow cost of posting a vacancy and $V$ its value while unfilled. Firms cannot post different types of vacancy for the unemployed entitled to UI and for those not entitled as it would be illegal otherwise. Then, the value of an unfilled vacancy can be written in terms of the expected value from a filled job $\left(J^{e}\right)$ :

$$
r V=-\gamma+A q(\theta)\left(J^{e}-V\right) .
$$


However, once a firm meets a worker, the firm may directly observe whether the candidate is entitled to UI, or can infer this from her labor market history. Thus, wages and the value of an occupied job are specific to the type of unemployed that fills the jobs. In particular, the value of a job filled by a type-1 unemployed worker is:

$$
r J_{1}=y_{1}-w_{1}+s_{1}\left(V-J_{1}\right)
$$

where $y_{1}$ is the productivity of a type- 1 employee, $w_{1}$ the bargained wage, and $V_{1}-J_{1}$ the capital loss born with separation probability $s_{1}$.

The value of a job filled with a type-2 unemployed worker differs from (13) in two respects. First, the worker's productivity $\left(y_{2}\right)$ and the separation rate $\left(s_{2}\right)$ may differ. ${ }^{9}$ Moreover, the employee gains eligibility with probability $p$, in which case the value of the job becomes $J_{1}$ :

$$
r J_{2}=y_{2}-w_{2}+s_{2}\left(V-J_{2}\right)+p\left(J_{1}-J_{2}\right) .
$$

The expression for the expected value of a filled job is given by:

$$
J^{e}=\mu J_{1}+(1-\mu) J_{2}
$$

where $\mu$ denotes the probability that a vacancy is filled by a worker eligible for UI, conditional on the event of meeting a worker. This probability is given by:

$$
\mu=\frac{u_{1}}{u_{1}+\lambda u_{2}} .
$$

Using (5) and (6) in (16),

$$
\mu=\frac{p A \theta q(\theta)}{p A \theta q(\theta)+d\left(s_{2}+p\right)} .
$$

Firms open vacancies up to the point where the expected value of posting a further vacancy is zero $(V=0)$. Then, from (12):

$$
J^{e}=\frac{\gamma}{A q(\theta)},
$$

stating that, in equilibrium, the expected income from a filled vacancy must equal the total costs of posting it. Using (15),

$$
\mu J_{1}+(1-\mu) J_{2}=\frac{\gamma}{A q(\theta)} .
$$

\subsection{Workers}

Workers are assumed to be risk-averse with instantaneous utility given by the isoelastic CRRA utility function $v(x)=x^{\eta} / \eta$, where $x$ is after-tax income. Let $U_{i}$ denote the asset value of unemployment when receiving type- $i$ benefit and $E_{i}$ the corresponding value for an employee eligible for type- $i$ benefit in case of separation. In a stationary environment,

$$
r U_{1}=v\left[b_{1}\left(1-\tau_{2}\right)\right]+A \theta q(\theta)\left(E_{1}-U_{1}\right)+d\left(U_{2}-U_{1}\right),
$$

\footnotetext{
${ }^{9}$ Note that we do not impose the constraint $y_{1}>y_{2}$. Empirically, as it will be shown in section 3 , UI-eligible workers have higher average wages, which stems from either a higher productivity, or from a stronger bargaining power.
} 
stating that an unemployed worker entitled to UI gets felicity $v[$.$] from after tax insurance benefit$ $b_{1}\left(1-\tau_{2}\right)$, makes a capital gain $E_{1}-U_{1}$ when finding a type- 1 job [with probability $A \theta q(\theta)$ ], and incurs into a capital loss $U_{2}-U_{1}$ when UI benefits expire (with probability $d$ ).

In turn, the expected discounted utility for a type-2 unemployed is:

$$
r U_{2}=v\left[b_{2}\right]+\lambda A \theta q(\theta)\left(E_{2}-U_{2}\right)
$$

i.e. while unemployed, the individual gets felicity $v\left[b_{2}\right]$, as her assistance benefit is not taxed, and makes a capital gain $E_{2}-U_{2}$ when finding a job.

Similarly, we have:

$$
r E_{1}=v\left[w_{1}\left(1-\tau_{1}-\tau_{2}\right)\right]+s_{1}\left(U_{1}-E_{1}\right),
$$

i.e. while employed and eligible for UI in case of separation, the individual has felicity $v\left[w_{1}(1-\right.$ $\left.\tau_{1}-\tau_{2}\right)$ ], as she finances both the UI and UA systems. Should a separation occur, she incurs into a capital loss of $U_{1}-E_{1}$. The expression for the expected utility from employment for a type-2 employee is similar, except that she becomes eligible for UI (i.e. a type-1 employee) with probability $p$ per unit of time:

$$
r E_{2}=v\left[w_{2}\left(1-\tau_{1}-\tau_{2}\right)\right]+s_{2}\left(U_{2}-E_{2}\right)+p\left(E_{1}-E_{2}\right) .
$$

\subsection{Wages}

\subsubsection{Type-2 employees}

Wages are the outcome of a bilateral Nash bargain between worker-firm pairs and can be renegotiated all the time. ${ }^{10}$ A type- 2 worker receives employment value $E_{2}$ if an agreement is reached and her threat point is $U_{2}$. For the firm, the expected value of a filled vacancy is $J_{2}$ and its threat point is $V$. The wage $w_{2}$ solves:

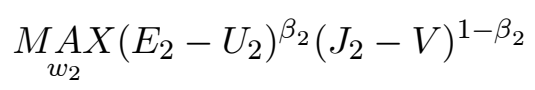

where $\beta_{2}$ is type- 2 worker's bargaining power. The optimality condition for this problem is:

$$
\left(1-\beta_{2}\right)\left(E_{2}-U_{2}\right)\left(1-\tau_{1}-\tau_{2}\right)^{\eta} \cdot w_{2}^{\eta-1}=\beta_{2}\left(J_{2}-V\right)
$$

Using (12), (14), and (23) in (25), we get:

$$
\beta_{2}\left[y_{2}-w_{2}-\frac{p\left(y_{1}-w_{1}\right)}{r+s_{1}}\right]\left(1-\tau_{1}-\tau_{2}\right)^{\eta} \cdot w_{2}^{\eta-1}=\left(1-\beta_{2}\right)\left[\frac{\left(1-\tau_{1}-\tau_{2}\right)^{\eta} \cdot w_{2}^{\eta}}{\eta}-(r+p) U_{2}+p E_{1}\right]
$$

\footnotetext{
${ }^{10}$ There are two reasons for assuming that UA recipients bargain over their monthly wage. First, the empirical evidence shows that the wage distribution of former UA recipients is non degenerate in France as two thirds are not paid the hourly legal minimum wage (Rioux, 2001b). Second, the monthly wage depends both on the hourly wage and on the number of hours worked. Even though the hourly wage is fixed at the minimum wage, the number of hours worked can still be bargained over. The empirical evidence shows a significant dispersion in the hours worked by the unemployed not entitled to UI when they find a job.
} 


\subsubsection{Type-1 employees}

Wages of type-1 workers solve:

$$
\underset{w_{1}}{\operatorname{AXX}}\left(E_{1}-U_{1}\right)^{\beta_{1}}\left(J_{1}-V\right)^{1-\beta_{1}}
$$

The optimality condition then verifies:

$$
\beta_{1}\left(y_{1}-w_{1}\right)\left(1-\tau_{1}-\tau_{2}\right)^{\eta} \cdot w_{1}^{\eta-1}=\left(1-\beta_{1}\right)\left[\frac{\left(1-\tau_{1}-\tau_{2}\right)^{\eta} \cdot w_{1}^{\eta}}{\eta}-r U_{1}\right] .
$$

\subsection{Equilibrium}

The equilibrium is defined as follows:

Definition 1 An equilibrium is a vector $\left(\theta, w_{1}, w_{2}, \tau_{1}, \tau_{2}, \mu, U_{1}, U_{2}, E_{1}, E_{2}, J_{1}, J_{2}\right)$ solving the system of twelve equations given by the value of unemployment and employment to workers [equations (20) to (23)], the value of filled jobs to firms [(13) and (14), with $V=0$ ], the free-entry condition (19), the FOC of the Nash bargains [(26) and (28)], the proportion of the unemployed entitled to $U I(17)$, and the budget constraints of the unemployment compensation systems [(9) and (11)].

Proposition 1 establishes the conditions under which wage dispersion arises in equilibrium:

Proposition 1 Let $y_{1} \geq y_{2}, \beta_{1} \geq \beta_{2}, b_{1}\left(1-\tau_{2}\right) \geq b_{2}$, and $s_{1}=s_{2}$. If UI eligibility is automatic $(p=+\infty)$, the Nash bargaining process yields to $w_{1}=w_{2}$. If UI eligibility is not automatic $(p<+\infty)$, then $w_{1}>w_{2}$.

Proof. See the appendix

Given that wages can be renegotiated all the time, when eligibility follows automatically from employment all workers have the same threat point and are paid the same wage (cf. Fredriksson and Holmlund, 2001). Indeed, if an employer was to propose a lower wage to UA recipients, then once hired the latter would threaten to quit and search to obtain elsewhere the same wage as other employees. In contrast, when UI eligibility requires a minimum duration of contributions, the unemployed not entitled to UI have a lower threat point, which gives rise to wage dispersion.

Wage dispersion is an important feature here, as it creates an incentive for UA recipients to accept jobs in order to be re-entitled to UI benefits. Endogenous search effort creates the same kind of incentives when eligibility is automatic (Fredriksson and Holmlund, 2001). However, this has the unrealistic feature that all types of workers are paid the same wage. ${ }^{11}$ For France, we believe wage dispersion to be more relevant than differences in search intensity. On the one hand, the wages of former UA and UI recipients are significantly different (see section 3 and Rioux, 2001a). In addition, Rioux (2001b) shows that the proportion of benefit recipients actively searching for a job are the same for UA and UI recipients, and that among active job seekers, the number of search

\footnotetext{
${ }^{11}$ The alternative hypothesis made by Cahuc and Lehmann (2000) that wages are negotiated by unions gives the same degenerate wage distribution.
} 
methods is similar for both groups. ${ }^{12}$ A search model where wages are posted by firms can also generate a non degenerate wage distribution, as shown by Albrecht and Vroman (2005). In their framework, time-varying unemployment benefits are sufficient to lead to a distribution of worker reservation wages. However this does not give rise to wage dispersion with certainty: a degenerate wage distribution is also one of the possible equilibria.

\subsection{Welfare}

In the welfare analysis, we compare steady state solutions and ignore the transition among steady states. Let $W$ denote the steady state utilitarian welfare function, $W_{w}$ the welfare of workers, and $W_{f}$ the welfare of firms, i.e.,

$$
W=W_{w}+W_{f}
$$

where

$$
W_{w}=e_{1} r E_{1}+e_{2} r E_{2}+u_{1} r U_{1}+u_{2} r U_{2}
$$

and

$$
W_{f}=e_{1} r J_{1}+e_{2} r J_{2}+v r V
$$

Substituting the explicit expression for the value functions (20)-(23) into $W_{w}$ and using the steady state equilibrium conditions (5)-(7),

$$
W_{w}=e_{1} v\left[w_{1}\left(1-\tau_{1}-\tau_{2}\right)\right]+e_{2} v\left[w_{2}\left(1-\tau_{1}-\tau_{2}\right)\right]+u_{1} v\left[b_{1}\left(1-\tau_{2}\right)\right]+u_{2} v\left[b_{2}\right],
$$

implying that $W_{w}$ simplifies to a weighted average of instantaneous utilities. Similarly, substituting (12)-(14) in $W_{f}$ and using (5)-(7), (16), and (19),

$$
W_{f}=e_{1}\left(y_{1}-w_{1}\right)+e_{2}\left(y_{2}-w_{2}\right)-\theta\left[u_{1}+\lambda u_{2}\right] \gamma
$$

i.e. $W_{f}$ simplifies to a weighted average of instantaneous profits minus the average cost of posting $\theta\left[u_{1}+\lambda u_{2}\right]=v$ vacancies. Finally, net output is given by:

$$
Y=e_{1} y_{1}+e_{2} y_{2}-\theta\left[u_{1}+\lambda u_{2}\right] \gamma
$$

\section{Estimation and calibration}

The existing literature (see e.g. Fredriksson and Holmlund, 2001, Albrecht and Vroman, 2005, Coles and Masters, 2006) provides more examples of qualitative effects of unemployment compensation systems than precise quantifications. Analytical results are typically derived in cases where workers are assumed to be risk-neutral (Albrecht and Vroman, 2005, Coles and Masters, 2006) or when there is no discounting (Fredriksson and Holmlund, 2001), while numerical calibrations are used in more general cases, and they are often constrained by the availability of parameters from a number of

\footnotetext{
${ }^{12}$ More precisely, two thirds of both UA and UI recipients use between two and four search methods. Data come from the 1998 Labor Force survey and from the 1998 Outcomes for RMI recipients Survey (Enquête Sortants du $R M I)$. Unfortunately, the ECHP does not contain information on the number and type of search methods used.
} 
external sources. ${ }^{13}$ In this work we go a step further and simulate the model using transition probabilities and earnings estimated on the 1994-2000 waves of the French sample of the ECHP. Being estimated on the same individuals and the same period, our parameter values are consistent with each other, which allows us to evaluate the quantitative impact of different reforms and the importance of the re-entitlement effect.

\subsection{The data set}

In October of each year, ECHP sampled individuals over 17 are asked to provide information on their personal characteristics and to retrospectively state their monthly labor market status during each month of the previous calendar year. As a result, the monthly (self-declared) labor market status (employed, unemployed, or inactive) of 9,686 individuals is available between January 1993 and December 2000. In addition, the data set provides monthly information on the source of earnings (wage, UA benefits, UI benefits, ...) and annual information on the amount of each type of earnings.

In principle, the data set directly provides monthly information on the entitlement status (UI or UA) of each unemployed individual. Moreover, the monthly level of each type of benefit could be computed as the annual amount divided by the number of months of receipt. However, the information on benefit type and on the annual amounts received is often missing, ${ }^{14}$ and subject to significant measurement error when available, as also stressed by Lollivier and Rioux (2006). Given these limitations, we reconstruct information on the type and level of benefits received by applying the eligibility rules of the French legislation on unemployment compensation (see also Pellizzari, 2006, and Lollivier and Rioux, 2006), and the relevant rules remained essentially unchanged between 1994 and 2000. ${ }^{15}$ This same method is used to determine whether employees are eligible for UI benefits in case of job loss.

\subsubsection{The French unemployment compensation system}

In France, the level and the maximum duration of UI benefits for an individual entering unemployment depend on the age, the past wage, and the duration of contributions of the beneficiary (see Table A1 in the appendix for full details). Two points are worth noting. First, eligibility for insurance benefits requires 4 months of contribution during the 8 months that preceded the unemployment spell. Second, if a UI recipient finds a job before exhaustion of benefits, she would automatically be eligible for UI benefits if she was to lose her new job. For this new unemployment

\footnotetext{
${ }^{13}$ For example, Fredriksson and Holmlund (2001) use parameter values provided by Wang and Williamson (1996), the OECD (1997), and Layard, Nickell, and Jackman (1991), some estimated on 1983-1996 and the others on 19841989.

${ }^{14}$ For example, in December 1997, the number of individuals registered for unemployment insurance according to the UI agency (Unedic) was 2,351,549, while the corresponding number in the (weighted) ECHP was roughly $30 \%$ lower, equal to $1,631,262$. Similarly, 956,132 individuals were receiving UA benefits according to the UA agency (Cnaf), and only 385,809 , i.e. $60 \%$ less, according to the ECHP.

${ }^{15}$ Only a minor change occurred in January 1997. Before this date, the UI benefit level was reduced by a fixed percentage every four months. After this date, it was reduced every six months. In contrast, a major reform of the UI rules was decided in January 2001 and implemented in July of the same year. For this reason, we do not use the ECHP survey after December 2000.
} 
spell, the benefit duration is equal to the maximum of her new entitlement and the remainder of her past entitlement.

The unemployed who exhaust their UI entitlement are eligible for a permanent (and flat) unemployment benefit (the Special Solidarity Allowance or Allocation de Solidarité Spécifique) provided they have worked at least five years during the ten years preceding their entry into unemployment. Because of this strong eligibility condition, this benefit is treated here as an insurance benefit, and the beneficiaries are considered as type-1 unemployed.

Finally, all the unemployed who fail to meet the UI eligibility criteria or have exhausted their entitlement ${ }^{16}$ can still receive a permanent, means tested social assistance benefit, the RMI (Revenu Minimum d'Insertion), which is essentially added to the household income so as to reach a minimum income level. While the actual benefit received varies thus across households depending on their composition and income level, here we assume that each unemployed not entitled to UI receives the maximum benefit level. ${ }^{17}$

\subsubsection{Monthly series of UI eligibility and entitlement}

Like for most welfare systems, the French UI/UA eligibility rules are fairly complicated, and we try here to make the best possible use of our data set in order to apply the relevant rules to the individuals in our sample.

We first apply the rules to the employed workers of our sample. According to Table A1, any employee who has worked for at least 4 months during the preceding 8 months or whose past UI benefits are not exhausted, is eligible for UI benefits upon future job loss, and in our model this means being a type- 1 employee. If neither of these conditions is satisfied, an employee losing her job is only eligible for UA benefits, and is thus a type- 2 employee. Since the retrospective employment history goes back to January 1993, we can construct a monthly series of UI eligibility for the employed from September 1993 onwards.

Determining whether an unemployed worker of our sample is entitled to UI in a given month is somewhat more complicated since both her maximum benefit duration and her unemployment duration need to be known. While the latter is directly available in the data set, the former depends on the length of her contributions to UI during the 24 months ${ }^{18}$ preceding unemployment and has to be reconstructed using the monthly information on employment status. Since the retrospective employment history goes back to January 1993, this method allows to reconstruct the UI entitlement status for all the individuals who entered unemployment after December 1994. In practice, we can also determine the UI entitlement status for an extremely large proportion of the individuals who entered unemployment during 1994, ${ }^{19}$ and thus apply this method from January 1994. All the

\footnotetext{
${ }^{16}$ Except those below 25 and without children.

${ }^{17}$ In December 1997, for example, two out of three beneficiaries received the maximum benefit level (Collin, 2000).

${ }^{18}$ For the unemployed aged 55 or less. For the older, the employment history over the preceding 37 months is needed to determine the maximum benefit duration. When this information is not available, they are treated as the individuals over 50, with a maximum entitlement of 45 months. Note that they represent only $2.5 \%$ of the unemployment spells.

${ }^{19}$ For instance, if, when entering unemployment, the individual has worked at least 14 months since January 1993, then she is entitled to 30 months of benefits which is the maximum duration and this allows us to determine her UI eligibility status over the unemployment spell. We can also determine the monthly UI eligibility status during all the
} 
unemployed not eligible for UI benefits are considered as UA recipients (type-2 unemployed, in our model).

In this way, we are able to reconstruct the monthly series of UI eligibility for 9,515 individuals from January 1994 to December 2000.

\subsection{Transitions}

Let $n_{i}(t-1)$ denote the number of individuals in labor market state $i$ at date $t-1$ and $n_{i, j}(t)$ the number of individuals who transit from state $i$ to state $j$ between periods $t-1$ and $t$. The maximum likelihood estimator of the monthly transition probability ${ }^{20}$ from $i$ to $j$ is then given by: $\widehat{p}_{i, j}=\frac{\sum_{t=1}^{T} n_{i, j}(t)}{\sum_{t=1}^{T} n_{i}(t-1)}$.

In accordance with the legislation, and as represented in Figure 1, there can only exist six types of transitions, namely job separations for each type of employee, job findings for each type of unemployed, and changes in eligibility status for either the employed or the unemployed. Table 1 reports the estimated monthly transition probabilities for the overall population, and their model counterpart, having imposed a Cobb-Douglas matching function with constant returns to scale with parameter $\frac{1}{2}$, implying $q(\theta)=\theta^{-\frac{1}{2}}$.

Table 1: The estimated monthly transition probabilities (\%)

\begin{tabular}{c|l|l|l|l|l}
\hline$s_{1}$ & $s_{2}$ & $A \theta^{\frac{1}{2}}$ & $\lambda A \theta^{\frac{1}{2}}$ & $p$ & $d$ \\
\hline \hline 0.78 & 3.6 & 7.7 & 4.8 & 23 & 3.1 \\
\hline
\end{tabular}

Source: French sample of the ECHP, Insee, 1994-2000.

The separation probability is much higher for type- 2 jobs, because most of them are fixed-term or temporary jobs. However, it is worth noting that the transformation probability of type- 2 jobs into type- 1 jobs is quite high, around $23 \%$. As a consequence, a type- 2 employee has a much higher probability of becoming eligible the next month than of losing her job. UI recipients find a job more quickly than UA recipients (with a $7.7 \%$ transition probability for the former versus $4.8 \%$ for the latter). Lastly, $3.1 \%$ of UI recipients exhaust their entitlement each month and become UA recipients.

The steady state equilibrium conditions (5)-(7) are completely determined by the transition rates $\left(s_{1}, s_{2}, p, d, A \theta^{\frac{1}{2}}, \lambda A \theta^{\frac{1}{2}}\right)$. This allows us to test whether the dynamic structure of the model (Figure 1) is accurate. Using the estimated transition rates, we simulate the unemployment rate and the proportion of the unemployed who receive UI benefit payments (also known as the UI recipiency rate), and in Table 2 we compare them with the official figures provided by the French Institute of Statistics and the UI agency for 1994-2000.

Figures in Table 2 show that the model seems to take into account all the relevant labor

unemployment spell when the effective unemployment duration is shorter than the maximum benefit duration.

${ }^{20}$ Since the matching model is in continuous time, one should, strictly speaking, estimate transition rates. Nevertheless, the maximum likelihood estimator of the monthly transition probability is a very good proxy of the maximum likelihood estimator of the transition rate. 
Table 2: Comparison between simulated and observed rates

\begin{tabular}{cc|cc}
\hline \multicolumn{2}{c|}{ Unemployment rate (\%) } & \multicolumn{2}{c}{ UI recipiency rate (\%) } \\
\hline \hline Simulated & Observed & Simulated & Observed \\
\hline 11.1 & 11.7 & 57.2 & 55.2 \\
\hline \hline
\end{tabular}

Notes: The simulated rates are computed using the French sample of the ECHP, Insee, 1994-2000. The observed unemployment rate is the mean over 1994-2000 of the annual rates, as provided by the Institute of Statistics (Insee). The observed UI recipiency rate is provided by the UI agency (Unedic).

market transitions, as it reproduces well the observed unemployment rate and provides a good approximation for the UI recipiency rate.

\subsection{Earnings}

We first need to compute the monthly wages in type- 1 and type- 2 jobs. This is done using the annually reported wages and the employment histories of workers. More precisely, we first compute the number of months during which a given individual has occupied respectively a type-1 and a type-2 position, and then average out across workers to get the average monthly wage associated to each position. As the entitlement status is related to job tenure, type- 1 employees typically receive a better wage than type- 2 employees, as reported in Table 3 . It is also worth noting that the average wage paid in type-2 jobs is above the legal minimum wage (€798 on average over 1994-2000), which motivates our hypothesis of a negotiated wage for type- 2 jobs versus the alternative hypothesis of an exogenously determined wage.

Table 3: The estimated wages and unemployment benefits (euros)

\begin{tabular}{c|c|c|c}
\hline$w_{1}$ & $w_{2}$ & $b_{1}$ & $b_{2}$ \\
\hline \hline 1430 & 819 & 649.4 & 323.6 \\
\hline
\end{tabular}

Source: French sample of the ECHP, Insee, 1994-2000.

The UI benefit received by a given unemployed individual in each month is constructed using the UI legislation. First, from the duration of contributions, the age, and the previous labor earnings, we infer the UI category each unemployed individual belongs to and the benefit paid at the beginning of the unemployment spell. This "full rate" benefit $b_{1}(1)$ is:

$$
b_{1}(1)=\min \left[\max \left\{c+0.404 \times w, 0.574 \times w, \underline{b_{1}}(1)\right\}, 0.75 \times w, \overline{b_{1}}(1)\right],
$$

where $w$ denotes the previous labor earnings (inclusive of social contributions paid by the employee), $c$ denotes a constant, $\underline{b_{1}}(1)$ the lower bound of the full-rate benefit, and $\overline{b_{1}}(1)$ the upper bound.

Second, applying the rules of this UI category (see the table A1), we simulate the time sequence of benefits. More precisely, the benefit is reduced by a fixed percentage (15 or $17 \%$ depending on the category to which the unemployed individual is assigned) every four months until December 1996 and every 6 months from January 1997. Then, the UI unemployment benefits are averagedout across individuals, which gives $b_{1}$. Finally, each UA recipient is affected a monthly income $b_{2}$ corresponding to full RMI allowance (€323.6 on average in the period under consideration). From 
the estimated transition rates and earnings, the equilibrium tax rates $\tau_{1}$ and $\tau_{2}$ are deduced using the budget constraints of each system (respectively (9) and (11)).

\subsection{Calibration}

The ECHP survey thus allows to estimate most of the parameters $\left(s_{1}, s_{2}, p, d, \lambda, b_{1}, b_{2}\right)$ and some of the endogenous variables $\left(A \theta^{\frac{1}{2}}, w_{1}, w_{2}\right)$ of the model. However, it does not provide any information on the eight remaining parameters, namely the cost of posting a vacancy $\gamma$, the scale parameter of the matching function $(A)$, the productivity in type- 1 and type- 2 jobs, $y_{1}$ and $y_{2}$, the discount rate $r$, the relative risk aversion coefficient $1-\eta$, and the bargaining power of type- 1 and type- 2 workers, $\beta_{1}$ and $\beta_{2}$. For the model to be identified, we have to make additional assumptions on five of these parameters. Two alternative sets of additional hypotheses will be used.

In the first set (referred to as the "benchmark calibration"), we assume that $r=0.01, \eta=-0.5$, $A=0.05$, and $\beta_{1}=\beta_{2}=0.5$. The values chosen for $r$ and $\eta$ are standard in the literature, while $\beta_{1}=\beta_{2}=0.5$ satisfies the Hosios (1990) rule. Then $\gamma, y_{1}$, and $y_{2}$ can be deduced so as to match the endogenous variables $\left(\theta^{\frac{1}{2}}, w_{1}, w_{2}\right)$ using the chosen and estimated parameters. Table 4 presents the chosen and deduced parameters. It is worth noting that the assumption of equal bargaining power implies that type-1 and type-2 employees must differ in their productivity.

Table 4: Other parameters

\begin{tabular}{l|llllllll}
\hline & $\gamma$ & $A$ & $y_{1}$ & $y_{2}$ & $\beta_{1}$ & $\beta_{2}$ & $r$ & $\eta$ \\
\hline \hline Benchmark calibration & 800 & 0.05 & 1895 & 842 & 0.5 & 0.5 & 0.01 & -0.5 \\
Alternative calibration & 789 & 0.05 & 1835 & 1835 & 0.52 & 0.475 & 0.01 & -0.5 \\
\hline \hline
\end{tabular}

In the second set of hypotheses (referred to as the "alternative calibration"), we assume $r=0.01$, $\eta=-0.5, A=0.05$, and $y_{1}=y_{2}$. In this case, $\gamma, \beta_{1}$, and $\beta_{2}$ are deduced, and we obtain that the two types of agents differ in their bargaining power. In the rest of the paper, we will concentrate on the quantitative results obtained in the benchmark calibration, and discuss the results with the alternative set of parameters only when they are significantly different.

\section{Reforming unemployment compensation}

We next simulate the effects on unemployment, wages, taxes, welfare, and output, of different reforms to the French unemployment compensation system. We examine in turn five reforms that would make the unemployment compensation system more generous: (i) a 10\% increase in the assistance benefit level; (ii) a $10 \%$ increase in the insurance benefit level; (iii) a 3-month increase in the duration of UI entitlement; (iv) a 2-week reduction in the employment duration required for UI eligibility; and finally (v) a radical reform that unifies the unemployment compensation system.

\subsection{Raising assistance benefits by $10 \%$}

Consider first a $10 \%$ increase in the assistance benefit level $b_{2}$. This strengthens the threat point of UA recipients $\left(U_{2}\right)$ in the bargaining process and enables them to negotiate a wage $w_{2}$ higher 
by $3.75 \%$ (see table 5), a standard result in the matching literature. In addition, from (20), this reform improves the threat point of UI beneficiaries who negotiate a wage $w_{1}$ higher by $0.6 \%$. Note that the rise in $w_{1}$ is much smaller than the rise in $w_{2}$ since UI entitlement is only lost with probability 0.031 each month. Then, both wages being higher, firms open fewer vacancies, and $\theta$ falls. Unsurprisingly, a higher unemployment rate $(+2.25 \%)$ is thus associated to this reform. In addition, more UI recipients tend to exhaust their entitlement and start receiving assistance benefits, which translates into a lower equilibrium UI recipiency rate $\left(\frac{u_{1}}{u}\right)$.

Table 5: A 10\% increase in assistance benefits

\begin{tabular}{c|ccccccccc}
\hline$b_{2}$ & $w_{1}$ & $w_{2}$ & $A \theta^{\frac{1}{2}}$ & $u_{1}$ & $u_{2}$ & $u$ & $\frac{u_{1}}{u}$ & $\tau_{1}$ & $\tau_{2}$ \\
\hline \hline 323.6 & 1430.5 & 828.9 & 7.69 & 6.36 & 4.76 & 11.12 & 57.21 & 3.26 & 1.18 \\
355.96 & 1439.1 & 860 & 7.52 & 6.44 & 4.93 & 11.37 & 56.66 & 3.29 & 1.34 \\
\hline \hline
\end{tabular}

This reform improves workers' welfare in each of the four labor market states, as shown in table 6 , but is not Pareto-improving for workers. Indeed, the increase in type-2 unemployment triggered by the reform implies that more workers end up in a low-utility state.

Clearly, UA recipients are those who benefit the most, as they receive a higher benefit and are exempted from paying higher taxes in the present. This leads their expected utility to rise by $1.5 \%$. For the three other groups, the possibility of receiving higher UA benefits in the future quantitatively dominates the negative effects associated to higher $\operatorname{taxes}^{21}$ and lower transitions into employment. Moreover, the groups whose transition rate from their current state into social assistance is higher benefit more from the reform.

On the whole, despite lower employment and UI recipiency rate, the utilitarian welfare of workers $\left(W_{w}\right)$ is slightly higher. By contrast, firms experience a $2.27 \%$ decline in their welfare due to higher wages. Yet, aggregate net output $(Y)$ declines only very slightly. ${ }^{22}$

Table 6: Welfare effects of a $10 \%$ increase in assistance benefits

\begin{tabular}{l|lllllll}
\hline$b_{2}$ & $U_{1}$ & $U_{2}$ & $E_{1}$ & $E_{2}$ & $W_{w}$ & $W_{f}$ & $Y$ \\
\hline \hline 323.6 & 93.88 & 85.45 & 101.43 & 98.21 & 100 & 217.66 & 1483.9 \\
355.96 & 94.40 & 86.76 & 101.80 & 98.80 & 100.41 & 212.71 & 1483.2 \\
\hline \hline
\end{tabular}

Note: Workers' welfare is measured with respect to a reference value $W_{w} \equiv 100$ before the reform.

\footnotetext{
${ }^{21}$ The tax rate $\tau_{2}$ needs to be raised by $13.6 \%$ to balance the budget of the social assistance agency instead of $10 \%$ if the behavior of workers and firms did not change after the reform. This is because the reform raises the number of UA recipients, which simultaneously increases assistance expenditures and lowers tax receipts, as the type-2 unemployed do not pay taxes. In addition, the tax financing UI expenditures $\left(\tau_{1}\right)$ has to go up to a small extent $(0.9 \%)$ due to the higher number of UI recipients.

${ }^{22}$ The utilitarian aggregate welfare, $W$, follows almost exactly the evolution of $W_{w}$, and declines by $2.275 \%$. This is not surprising, as our choice of the utility function implies that $W_{w}=-0.058$ while $W_{f}=217.66$. Clearly, any relative change in $W_{w}$ has then a negligible weight in the evolution of $W=W_{w}+W_{f}$, which is completely driven by the evolution of $W_{f}$.
} 


\subsection{Raising insurance benefits by $10 \%$}

Raising the insurance benefit $b_{1}$ by $10 \%$ improves the threat point of UI recipients, which raises the wage of the employees eligible for UI benefits by $0.73 \%$ (see table 7 ). The elasticity of $w_{1}$ with respect to $b_{1}$ is thus much smaller than the elasticity of $w_{2}$ with respect to $b_{2}(0.375)$, and is close to the elasticity of $w_{1}$ with respect to $b_{2}(0.07)$.

After the rise in $b_{1}$, a type-2 employee eventually gaining UI eligibility is now also paid a better wage and receives a higher UI benefit upon future separation. As a consequence, getting a type-2 job becomes more attractive in the first place, which puts downward pressure on $w_{2}$. This impact is shown to be quantitatively important, as $w_{2}$ decreases by $2.62 \%$.

Both the small positive impact of $b_{1}$ on $w_{1}$ and the large negative impact of $b_{1}$ on $w_{2}$ are due to a mechanism close to the entitlement effect first identified by Mortensen (1977) in a search framework, and later extended to a matching framework by Fredriksson and Holmlund (2001), Albrecht and Vroman (2005), or Coles and Masters (2004, 2006). Specifically, Mortensen (1977) shows that higher UI benefits or longer entitlement make current employment more attractive for the unemployed not entitled to UI benefits, and this lowers their reservation wage. In our paper, this result is corroborated in a general equilibrium model with endogenous wages, as $w_{2}$ is decreasing in $b_{1}$.

In addition, Mortensen (1977) argues that the standard disincentive effect of UI, which increases workers' reservations wages and thus lowers job acceptance rates, should dominate over re-entitlement effects for the unemployed at the beginning of their UI entitlement. This is also what we find here, as $w_{1}$ increases with $b_{1}$. However, the small elasticity of $w_{1}$ with respect to $b_{1}$ suggests that entitlement effects may be quantitatively relevant. Note finally that the wages of the two types of employees can move in opposite directions after a change in the unemployment compensation system because the two types of unemployed have different threat points due to non-automatic eligibility.

Table 7: A 10\% increase in insurance benefits

\begin{tabular}{c|ccccccccc}
\hline$b_{1}$ & $w_{1}$ & $w_{2}$ & $A \theta^{\frac{1}{2}}$ & $u_{1}$ & $u_{2}$ & $u$ & $\frac{u_{1}}{u}$ & $\tau_{1}$ & $\tau_{2}$ \\
\hline \hline 649.43 & 1430.5 & 828.9 & 7.69 & 6.36 & 4.76 & 11.12 & 57.21 & 3.26 & 1.18 \\
714.373 & 1440.9 & 807.2 & 7.51 & 6.45 & 4.94 & 11.39 & 56.63 & 3.62 & 1.21 \\
\hline \hline
\end{tabular}

The average wage of the two types of employees increases as a result of the reform, and firms choose to open fewer vacancies, which results in a higher unemployment rate $(+2.43 \%)$. Thus more UI recipients exhaust their entitlement and the UI recipiency rate falls. It is worth noting that the fall in the matching probability and the UI recipiency rate, and the rise in the unemployment rate are very close to those observed after a $10 \%$ increase in $b_{2} \cdot{ }^{23}$ The main difference between these two

\footnotetext{
${ }^{23}$ The two reforms differ in their quantitative impact on taxes. More precisely, for both reforms, the tax financing the benefit which is increased has to be raised more than proportionally $\left(+11 \%\right.$ for $\tau_{1}$ after a $10 \%$ rise in $b_{1},+13.6 \%$ for $\tau_{2}$ after a $10 \%$ rise in $b_{2}$ ), while the opposite holds true for the other tax. However, a more generous UI benefit is accompanied by a much higher increase in $\tau_{2}(+2.5 \%)$ than the rise in $\tau_{1}(+0.9 \%)$ associated to more generous UA benefits. This difference is due to the asymmetric structure of the unemployment compensation system. Indeed, the type-1 unemployed eventually exhaust their rights to UI and become UA recipients, while there does not exist a
} 
policies resides in their welfare implications (see table 8). While more generous assistance benefits improve the welfare of all groups of workers, the type- 2 unemployed lose from a $10 \%$ increase in $b_{1}$. This follows from both a lower unemployment exit rate and lower wages. Unsurprisingly, the type1 unemployed benefit the most from an increase in $b_{1}$, followed by type- 1 employees, who would enjoy higher $b_{1}$ upon job loss. Type- 2 employees are the next in line and only slightly better-off, as they first have to gain eligibility before being able to enjoy higher wages and higher benefits upon job loss. On top of this effect, also accounted for at fixed wages by Mortensen (1977), Nash-wage bargaining implies that their wages fall slightly as the value of employment rises relative to their outside option.

Table 8: Welfare effects of a $10 \%$ increase in insurance benefits

\begin{tabular}{l|lllllll}
\hline$b_{1}$ & $U_{1}$ & $U_{2}$ & $E_{1}$ & $E_{2}$ & $W_{w}$ & $W_{f}$ & $Y$ \\
\hline \hline 649.43 & 93.88 & 85.45 & 101.43 & 98.21 & 100 & 217.66 & 1483.9 \\
714.373 & 94.42 & 85.35 & 101.78 & 98.4 & 100.29 & 211.76 & 1483.1 \\
\hline \hline
\end{tabular}

Note: Workers' welfare is measured with respect to a reference value $W_{w} \equiv 100$ before the reform.

\subsection{A 3-month increase in the duration of UI entitlement}

In our model, the average duration of benefit receipt, conditional on not finding a job, is $1 / d$, where $d$ is the Poisson transition rate from type- 1 to type-2 unemployment. We now consider a 3-month increase in the UI benefit duration, specifically from 32.26 to 35.26 months, which corresponds to a fall in $d$ from 3.1 to $2.836 .{ }^{24}$ Similarly as with the increase in $b_{1}$, this reform makes employment more attractive for UA recipients, while UI beneficiaries are now less eager to accept a job. The re-entitlement effect thus explains why $w_{2}$ falls by $1.22 \%$, while $w_{1}$ only increases by $0.35 \%$ after this large increase in duration (see table 9). We unsurprisingly observe a fall in UA recipients $\left(u_{2}\right)$ accompanied by a rise in UI recipients $\left(u_{1}\right)$. More interestingly, the fall in $u_{2}(-4.83 \%)$ is larger than the rise in $u_{1}(+3.14 \%)$, implying that unemployment slightly falls (by $0.27 \%$ ) after the reform.

Note however that this fall in unemployment is due to the changed composition of unemployment, and specifically to the fact that UI recipients, who now represent a larger portion of the unemployed, search more effectively than UA recipients $(\lambda<1)$. While an undesirable feature of this model is that unemployed workers would search more effectively simply as a consequence of extended UI benefit duration, one could think of mechanisms that would yield a positive reaction of search intensity to benefit payments, for example through higher resources available for active job search (see for example Barron and Mellow, 1979, Tannery, 1983, Jones, 1989, or Wadsworth, 1991).

direct transition from type-2 to type-1 unemployment. As a consequence, both reforms lead to a higher increase in $u_{2}$ than in $u_{1}$, and thus $\tau_{2}$ needs to be raised more than $\tau_{1}$.

${ }^{24}$ This reform corresponds to a $9.3 \%$ rise in total benefit duration. However, once we consider that the type- 1 unemployed transit into employment with probability $7.69 \%$ before the reform, the ex ante effective duration of benefit receipt is $1 /\left(d+A \theta^{\frac{1}{2}}\right)$ and thus the ex ante financing cost to the UI agency (given by $\left.b_{1} u_{1}\right)$ increases only by $2.7 \%$. By ex ante, we mean taking $w_{1}, w_{2}$, and $\theta$ as given. 
Table 9: A 3-month increase in the duration of UI entitlement

\begin{tabular}{c|ccccccccc}
\hline$d$ & $w_{1}$ & $w_{2}$ & $A \theta^{\frac{1}{2}}$ & $u_{1}$ & $u_{2}$ & $u$ & $\frac{u_{1}}{u}$ & $\tau_{1}$ & $\tau_{2}$ \\
\hline \hline 3.1 & 1430.5 & 828.9 & 7.69 & 6.36 & 4.76 & 11.12 & 57.21 & 3.26 & 1.18 \\
2.836 & 1435.5 & 818.8 & 7.63 & 6.56 & 4.53 & 11.09 & 59.18 & 3.35 & 1.12 \\
\hline \hline
\end{tabular}

Turning to welfare, all categories of workers are better-off after the reform (see table 10), and individuals with a higher transition rate into type-1 unemployment benefit to a larger extent. Unsurprisingly, UI recipients benefit the most from this reform $(+0.36 \%)$. This is because their gain is immediate and they have to pay lower taxes. Indeed, $\tau_{1}$ has to be raised only by $2.76 \%$, as both the number of taxpayers and the average wage slightly increase, while $\tau_{2}$ significantly decreases $(-5.08 \%)$. In contrast to the previous reform, UA recipients are also better-off, because the fall in $w_{2}$ is more than compensated by better prospects whenever they transit into type-1 employment or unemployment. Finally, total output slightly increases $(+0.17 \%)$, following the rise in employment.

Table 10: Welfare effects of extending by 3 months UI entitlement

\begin{tabular}{l|lllllll}
\hline$d$ & $U_{1}$ & $U_{2}$ & $E_{1}$ & $E_{2}$ & $W_{w}$ & $W_{f}$ & $Y$ \\
\hline \hline 3.1 & 93.88 & 85.45 & 101.43 & 98.21 & 100 & 217.66 & 1483.9 \\
2.836 & 94.22 & 85.48 & 101.69 & 98.39 & 100.27 & 215.24 & 1486.5 \\
\hline \hline
\end{tabular}

Note: Workers' welfare is measured with respect to a reference value $W_{w} \equiv 100$ before the reform.

While both raising the UI benefit level and extending entitlement are two ways of making the UI system more generous, our results show that these two policies have opposite effects on aggregate output and welfare, and that extending entitlement may be preferable for several reasons. First, longer entitlement results in lower unemployment and higher output, while the opposite happens with higher UI benefits. Second, all groups of workers benefit from longer entitlement, while higher UI benefits damage the situation of the type-2 unemployed. In the appendix, we show that these results still hold if we design an increase in UI benefits whose ex ante additional cost to the unemployment compensation system matches the ex post additional cost of a 3-month increase in entitlement.

\subsection{A 2-week reduction in the employment spell required for UI eligibility}

We next study the effect of a 2-week reduction in the employment spell required for UI entitlement. In our model, the expected length of employment required for UI entitlement is $1 / p$, where $p$ is the Poisson transition rate from type- 2 to type- 1 employment. Initially, the monthly transition probability is equal to $23 \%$, implying an average requirement of 132 days of employment. After the reform, $p=25.72 \%$, i.e. $1 / p=118$ days. This corresponds to a $10.6 \%$ decrease in the employment requirement (or equivalently, a $11.8 \%$ increase in $p$ ).

Easier eligibility requirements have offsetting effects on $w_{2}$. First, the type-2 unemployed are more eager to get a type- 2 job, as they expect to become eligible for UI benefits more rapidly. This 
puts downward pressure on the wage they negotiate. At the same time, it is always more profitable for firms to hire a type-1 unemployed worker than a type-2 unemployed worker given that $s_{1}<s_{2}$. Then, as type- 2 jobs become more easily type- 1 jobs after the reform, the value of a job filled by a type-2 individual rises and firms respond by opening more vacancies, which tends to increase $w_{2}$. Whether the wage paid to type-2 employees rises or falls thus depends on which effect dominates. In the benchmark calibration, the second effect is particularly strong since there is an additional efficiency gain after the reform stemming from the assumptions $y_{1}>y_{2}$ and $\beta_{1}=\beta_{2}$. As a result, this effect dominates, which explains why both $w_{2}$ and $A \theta^{1 / 2}$ rise after the reform (see table 11). Conversely, in the alternative calibration $\left(y_{1}=y_{2}\right.$ and $\left.\beta_{1}>\beta_{2}\right)$, the second effect is particularly weak, given that the employment composition is shifted towards workers with higher bargaining power but not higher productivity. This implies that both $w_{2}$ and $A \theta^{1 / 2}$ fall in this case.

Table 11: A two-week reduction in the employment spell required for UI entitlement

\begin{tabular}{c|ccccccccc}
\hline$p$ & $w_{1}$ & $w_{2}$ & $A \theta^{\frac{1}{2}}$ & $u_{1}$ & $u_{2}$ & $u$ & $\frac{u_{1}}{u}$ & $\tau_{1}$ & $\tau_{2}$ \\
\hline \hline 23 & 1430.5 & 828.9 & 7.69 & 6.36 & 4.76 & 11.12 & 57.21 & 3.26 & 1.18 \\
25.72 & 1432.6 & 832.1 & 7.7 & 6.37 & 4.7 & 11.07 & 57.57 & 3.26 & 1.16 \\
\hline \hline
\end{tabular}

The choice of calibration is not determinant for the effects of the reform on the remaining variables. Unsurprisingly, $u_{1}$ rises and $u_{2}$ falls, but the fall in $u_{2}$ always dominates and thus aggregate unemployment falls, by $0.45 \%$ and $0.27 \%$ in the benchmark and the alternative calibrations, respectively. ${ }^{25}$ As for the welfare (see table 12), each group of workers is better-off after the reform. Type-2 employees benefit the most, as they obtain more quickly the wage increase associated with UI eligibility status, and pay lower taxes. For the other groups, the gain decreases with the distance from type-2 employment. Finally, net output rises slightly following the rise in employment, while firms' payoff worsens due to higher wages.

Table 12: Welfare effects of a two-week reduction in the employment spell required for UI entitlement

\begin{tabular}{l|lllllll}
\hline$p$ & $U_{1}$ & $U_{2}$ & $E_{1}$ & $E_{2}$ & $W_{w}$ & $W_{f}$ & $Y$ \\
\hline \hline 23 & 93.88 & 85.45 & 101.43 & 98.21 & 100 & 217.66 & 1483.9 \\
25.72 & 94.04 & 85.71 & 101.55 & 98.64 & 100.15 & 216.8 & 1486.2 \\
\hline \hline
\end{tabular}

Note: Workers' welfare is measured with respect to a reference value $W_{w} \equiv 100$ before the reform.

It is worth noting that, in our simulation, the positive effect of easier eligibility requirements on employment is partly over-estimated. As $s_{1}$ and $s_{2}$ are assumed to be exogenous, an increase in the proportion of type- 1 employees mechanically decreases the average risk of job loss. However, the empirical evidence shows that type-2 employees face a higher risk of job loss because they more often get fixed-term or temporary contracts. As the type of contract is independent from UI eligibility, becoming eligible for UI is clearly not sufficient to transform a temporary contract into a

\footnotetext{
${ }^{25}$ Regarding financing, in spite of the additional cost to the UI system, the tax rate $\tau_{1}$ does not need to be raised, as both the proportion of taxpayers (the employees) and the average wage increase. Moreover, as assistance expenditures are reduced and there are more taxpayers (the employees and UI recipients), $\tau_{2}$ decreases $(-1.69 \%)$.
} 
permanent contract. As a result, we expect easier eligibility requirements to be linked to a slightly higher average separation rate for type- 1 employees. Nevertheless, as we simulate a relatively small increase in $p(+11.8 \%)$ and the proportion of type-2 employees is initially small, it seems safe to argue that accounting for this additional element is unlikely to significantly alter our results.

When compared to longer benefit duration (see section 4.3), easier eligibility requirements have exactly the same qualitative effects. The only difference lies in the group of workers who benefit the most from the reform. A longer benefit duration benefits more the type-1 employed and unemployed, while making eligibility easier improves more the situation of the type- 2 employed and unemployed. As a consequence, making eligibility easier may be preferred with a social welfare function giving more weight to the least well-off individuals.

\section{$5 \quad$ Quantifying re-entitlement effects}

This section quantifies re-entitlement effects for France. To this purpose, we compare our model with a model as close as possible to ours but where re-entitlement is not at work. The model used for comparison is simply the standard Pissarides (2000) 2-state model (see appendix), where all the unemployed are indefinitely paid the same unemployment benefit and all the employees have the same rights to unemployment benefits after a job separation. Clearly, in that model, only the standard disincentive effect of unemployment benefits is at work. In our two-tier system, instead, we have seen that this standard effect is accompanied by a re-entitlement effect working in the opposite direction. The comparison between the two models is feasible because the Pissarides model is the limit of our model when $p \rightarrow+\infty$ and $d \rightarrow 0$. To precisely perform this comparison, the productivity, the separation rate, the unemployment benefit and the search intensity in the Pissarides model are set so as to match the ex post weighted averages obtained in our model, i.e. respectively $y \equiv \frac{e_{1} y_{1}+e_{2} y_{2}}{e_{1}+e_{2}}, s \equiv \frac{e_{1} s_{1}+e_{2} s_{2}}{e_{1}+e_{2}}, b \equiv \frac{u_{1} b_{1}+u_{2} b_{2}}{u_{1}+u_{2}}$, and $\bar{\lambda} \equiv \frac{u_{1}+u_{2} \lambda}{u_{1}+u_{2}}$. The remaining parameters $(d, \beta, r, \eta, A, \gamma)$ are common to both models (see values reported in Tables 1 and 4 ).

A first way of assessing the extent of re-rentitlement effects is to compare the equilibrium under both models. As expected, wages are higher in the absence of re-entitlement effects (i.e. in the Pissarides model) and, interestingly, the difference is non negligible $(+1.4 \%)$, as shown in Table 13 . Firms open fewer vacancies and thus unemployment is higher by $1.7 \%$. In spite of this, workers are better-off without re-entitlement effects, and in particular the welfare of the unemployed rises importantly $(+5.3 \%)$. Instead firms are worse-off by $6.8 \%$. Finally, aggregate welfare measured by total output remains almost constant, indicating that the welfare impact of re-entitlement effects is essentially distributional.

Table 13: Comparison between our two-tier system and a unified system

\begin{tabular}{l|lllllllll}
\hline & $w$ & $u$ & $A \theta^{\frac{1}{2}}$ & $E$ & $U$ & $W_{w}$ & $W_{f}$ & $Y$ & $\tau$ \\
\hline \hline Our model & 1424.7 & 11.12 & 7.69 & 101.41 & 90.27 & 100 & 217.7 & 1483.9 & 0.043 \\
Pissarides (2000) & 1444.3 & 11.31 & 7.55 & 102.16 & 95.08 & 101.3 & 202.9 & 1483.8 & 0.045 \\
\hline \hline
\end{tabular}

Alternatively, re-entitlement effects can be quantified by comparing the impact of a $10 \%$ increase 
in both $b_{1}$ and $b_{2}$ in our model with a $10 \%$ increase in $b \equiv \frac{u_{1} b_{1}+u_{2} b_{2}}{u_{1}+u_{2}}$ in the Pissarides model (Table 14). In relative terms, the rise in the average wage is $10 \%$ lower in our model, meaning that the re-entitlement effect is significant but small on wages. Re-entitlement has a stronger effect on unemployment, as it lowers by $12.8 \%$ the rise in $u$. The impact in relative terms is also important for distributional issues, as re-entitlement reduces by $10 \%$ the improvement of workers' welfare and by $15.3 \%$ the worsening of the situation of firms. The fall in output is also reduced by $14.3 \%$ due to higher labor demand.

Table 14: A $10 \%$ rise in $b_{1}$ and $b_{2}$, with and without re-entitlement effects (\%)

\begin{tabular}{c|cc}
\hline & Our model & Pissarides (2000) \\
\hline \hline$w$ & 1.34 & 1.49 \\
$u$ & 4.856 & 5.57 \\
$W_{w}$ & 0.71 & 0.79 \\
$W_{f}$ & -5.07 & -5.99 \\
$Y$ & -0.12 & -0.14 \\
\hline \hline
\end{tabular}

\section{Conclusion}

The model we propose in this article accounts for the main features of modern unemployment compensation systems, namely the existence of insurance and assistance benefits, the limited duration of insurance benefits, and the presence of eligibility requirements for UI. As UI eligibility does not automatically follow from employment, UA recipients and UI beneficiaries have different threat points, which generates equilibrium wage dispersion and creates an incentive for UA recipients to accept jobs in order to be re-entitled to UI benefits.

The model is simulated for one country, France, using parameters of interest estimated on the French sample of the ECHP. However, the method used to construct the monthly series of UI eligibility for both the employed and the unemployed, together with the benefit level received by the unemployed, is more general. In particular, it can be applied to any panel data set providing monthly information on employment status.

For the French case, we show that an increase in UI benefits or an extension of UI entitlement leads to a significant decrease in the wage negotiated by the unemployed not entitled to UI. While both reforms make unemployment insurance more generous, they have opposite impacts on unemployment and welfare. For the same ex ante cost, extending entitlement seems preferable. We also find that easier requirements for UI eligibility reinforce re-entitlement effects, which tends to lower unemployment. Finally, re-entitlement effects are shown to be empirically relevant for France, as they reduce the wage impact of a $10 \%$ increase in benefit levels by $10 \%$, and the unemployment effect by $13 \%$.

Yet, most of the recent reforms implement stricter eligibility requirements and/or shorter benefit durations, combined with a higher monitoring (as for instance in Germany, the Netherlands, and France). The extent of re-entitlement effects may help explain why these reforms have only a limited impact on the unemployment rate. 


\section{Appendix}

\section{(i) Proof of Proposition 1}

Proof. For $p=+\infty$, all workers have the same threat point and are paid the same wage, as wages can be renegotiated all the time. For $p<+\infty$, Proposition 1 is proved by contradiction. Assume $w_{1} \leq w_{2}$. Subtracting (14) from (13) gives: $\left(r+p+s_{1}\right) J_{1}-\left(r+p+s_{2}\right) J_{2}=\left(y_{1}-\right.$ $\left.y_{2}\right)-\left(w_{1}-w_{2}\right)$. Given that $y_{1} \geq y_{2}$ and $s_{1} \leq s_{2}, w_{1} \leq w_{2} \Rightarrow J_{1} \geq J_{2}$. The solutions to the Nash bargaining problems are given by: $E_{1}-U_{1}=\left(\frac{\beta_{1}}{1-\beta_{1}}\right) \frac{J_{1}}{\left(1-\tau_{1}-\tau_{2}\right)^{\eta} w_{1}^{\eta-1}}$ and $E_{2}-U_{2}=$ $\left(\frac{\beta_{2}}{1-\beta_{2}}\right) \frac{J_{2}}{\left(1-\tau_{1}-\tau_{2}\right)^{\eta} w_{2}^{\eta-1}}$. Then, subtracting the second equation from the first yields to: $E_{1}-U_{1}-$ $E_{2}+U_{2}=\left(\frac{1}{\left(1-\tau_{1}-\tau_{2}\right)^{\eta}}\right)\left[\left(\frac{\beta_{1}}{1-\beta_{1}}\right) \frac{J_{1}}{w_{1}^{\eta-1}}-\left(\frac{\beta_{2}}{1-\beta_{2}}\right) \frac{J_{2}}{w_{2}^{\eta-1}}\right]$. Since $\beta_{1} \geq \beta_{2}$, assuming $w_{1} \leq w_{2}$ implies that $E_{1}-U_{1}-E_{2}+U_{2} \geq 0$. Next, subtracting (23) from (22) and rearranging for $s_{1}=s_{2}=s$ gives:

$$
(r+p+s)\left(E_{1}-U_{1}-E_{2}+U_{2}\right)=v\left[w_{1}\left(1-\tau_{1}-\tau_{2}\right)\right]-v\left[w_{2}\left(1-\tau_{1}-\tau_{2}\right)\right]-(r+p)\left(U_{1}-U_{2}\right)
$$

From (20) and (21), assuming that $b_{1}\left(1-\tau_{2}\right) \geq b_{2}$ holds in equilibrium we get: $U_{1}-U_{2} \geq 0$. Therefore, if $w_{1} \leq w_{2}$, it follows that the right-hand side of (33) is negative. Then, $E_{1}-U_{1}-E_{2}+$ $U_{2} \leq 0$, which contradicts the assumption that $w_{1} \leq w_{2}$. Thus, $w_{1}>w_{2}$

\section{(ii) Table A1: Unemployment insurance rules in France}

A - January 1994 - December 1996

\begin{tabular}{|c|c|c|c|c|c|c|}
\hline Category & $\begin{array}{c}\text { Contribution } \\
\text { duration }\end{array}$ & Age & $\begin{array}{l}\text { Duration at full } \\
\text { rate (months) }\end{array}$ & $\begin{array}{l}\text { Stage duration } \\
\text { (months) }\end{array}$ & $\begin{array}{c}\% \text { of } \\
\text { decrease }\end{array}$ & $\begin{array}{c}\text { Compensation } \\
\text { duration (months) }\end{array}$ \\
\hline$\overline{0}$ & $\begin{array}{l}<4 \text { months during } \\
\text { the last } 8 \text { months }\end{array}$ & Indifferent & 0 & 0 & $\overline{0}$ & 0 \\
\hline 1 & $\begin{array}{l}4 \text { months during the } \\
\text { last } 8 \text { months }\end{array}$ & Indifferent & 0 & 4 & 25 & 4 \\
\hline 2 & $\begin{array}{l}6 \text { months during the } \\
\text { last } 12 \text { months }\end{array}$ & Indifferent & 4 & 4 & 15 & 7 \\
\hline $\begin{array}{l}3 \\
4\end{array}$ & $\begin{array}{l}8 \text { months during the } \\
\text { last } 12 \text { months }\end{array}$ & $\begin{array}{l}<50 \text { years } \\
\geq 50 \text { years }\end{array}$ & $\begin{array}{l}4 \\
7\end{array}$ & $\begin{array}{l}4 \\
4\end{array}$ & $\begin{array}{l}17 \\
15\end{array}$ & $\begin{array}{l}15 \\
21\end{array}$ \\
\hline $\begin{array}{l}5 \\
5 \\
6 \\
\end{array}$ & $\begin{array}{l}14 \text { months during the } \\
\text { last } 24 \text { months }\end{array}$ & $\begin{array}{c}<25 \text { years } \\
25-50 \text { years } \\
\geq 50 \text { years }\end{array}$ & $\begin{array}{c}7 \\
9 \\
15 \\
\end{array}$ & $\begin{array}{l}4 \\
4 \\
4 \\
\end{array}$ & $\begin{array}{l}17 \\
17 \\
15 \\
\end{array}$ & $\begin{array}{l}30 \\
30 \\
45 \\
\end{array}$ \\
\hline $\begin{array}{l}7 \\
8\end{array}$ & $\begin{array}{l}27 \text { months during the } \\
\text { last } 36 \text { months }\end{array}$ & $\begin{array}{l}50-55 \text { years } \\
\geq 55 \text { years }\end{array}$ & $\begin{array}{l}20 \\
27\end{array}$ & $\begin{array}{l}4 \\
4\end{array}$ & $\begin{array}{c}15 \\
8\end{array}$ & $\begin{array}{l}45 \\
60\end{array}$ \\
\hline
\end{tabular}

B - January 1997 - June 2001

\begin{tabular}{|c|c|c|c|c|c|c|}
\hline Category & $\begin{array}{c}\text { Contribution } \\
\text { duration }\end{array}$ & Age & $\begin{array}{l}\text { Duration at full } \\
\text { rate (months) }\end{array}$ & $\begin{array}{l}\text { Stage duration } \\
\text { (months) }\end{array}$ & $\begin{array}{c}\% \text { of } \\
\text { decrease }\end{array}$ & $\begin{array}{l}\text { Compensation } \\
\text { duration (months) }\end{array}$ \\
\hline 0 & $\begin{array}{l}<4 \text { months during } \\
\text { the last } 8 \text { months }\end{array}$ & Indifferent & 0 & 0 & 0 & 0 \\
\hline 1 & $\begin{array}{l}4 \text { months during the } \\
\text { last } 8 \text { months }\end{array}$ & Indifferent & 4 & 0 & 0 & 4 \\
\hline 2 & $\begin{array}{c}6 \text { months during the } \\
\text { last } 12 \text { months }\end{array}$ & Indifferent & 4 & 6 & 15 & 7 \\
\hline 3 & 8 months during the & $<50$ years & 4 & 6 & 17 & 15 \\
\hline 4 & last 12 months & $\geq 50$ years & 7 & 6 & 15 & 21 \\
\hline 5 & 14 months during the & $<50$ years & 9 & 6 & 17 & 30 \\
\hline 6 & last 24 months & $\geq 50$ years & 15 & 6 & 15 & 45 \\
\hline 7 & 27 months during the & $50-55$ years & 20 & 6 & 15 & 45 \\
\hline 8 & last 36 months & $\geq 55$ years & 27 & 6 & 8 & 60 \\
\hline
\end{tabular}


(iii) Higher UI benefits vs. longer UI entitlement with the same ex ante cost

Consider the 3-month increase in UI entitlement studied above. The ex post additional cost to the unemployment compensation system is given by $b_{1}\left(u_{1}^{\prime}-u_{1}\right)+b_{2}\left(u_{2}^{\prime}-u_{2}\right)$ where $u_{i}^{\prime}$ denotes the type- $i$ unemployment rate after the reform. The increase in UI benefits is then designed such that the ex ante additional cost of this reform equals the ex post cost of longer benefit duration, i.e. $b_{1}^{\prime}-b_{1}=\frac{b_{1}\left(u_{1}^{\prime}-u_{1}\right)+b_{2}\left(u_{2}^{\prime}-u_{2}\right)}{u_{1}}=8.7198$. Thus, we compare a 3 -month increase in UI entitlement with a rise in $b_{1}$ from 649.43 to 658.1498 .

Table 15: Comparing reforms with identical ex ante cost to the unemployment compensation system: longer UI entitlement vs. higher UI benefits (\%)

\begin{tabular}{l|cccccccccccc}
\hline & $w_{1}$ & $w_{2}$ & $u_{1}$ & $u_{2}$ & $u$ & $U_{1}$ & $U_{2}$ & $E_{1}$ & $E_{2}$ & $W_{w}$ & $W_{f}$ & $Y$ \\
\hline \hline longer entitlement & .34 & -1.22 & 3.14 & -4.83 & -.27 & .36 & .04 & .26 & .18 & .27 & -1.11 & .175 \\
higher benefits & .1 & -.37 & .16 & .42 & .27 & .08 & -.02 & .05 & .03 & .04 & -.4 & -.006 \\
\hline \hline
\end{tabular}

As in the simulations presented in section 4.2, we find that raising UI benefits results in higher unemployment and lower output, and that the type-2 unemployed are worse-off after the reform. When comparing the welfare effects, we find that higher UI benefits increase less workers' welfare than longer benefit duration, while firms' welfare is reduced to a smaller extent.

\section{(iv) A version of Pissarides (2000)}

We use the standard Pissarides model with exogenous search efficiency. Then, in the steadystate equilibrium, $u=\frac{s}{s+\bar{\lambda} A \theta q(\theta)}$ and $e=\frac{\bar{\lambda} A \theta q(\theta)}{s+\bar{\lambda} A \theta q(\theta)}$, while $\tau_{1}=\frac{b s}{w \bar{\lambda} A \theta q(\theta)}$ and $\tau_{2}=0$. The expected discounted values of employment and unemployment are respectively given by $r E=$ $v\left[w\left(1-\tau_{1}-\tau_{2}\right)\right]+s\left(U_{1}-E\right)$ and $r U=v\left[b\left(1-\tau_{2}\right)\right]+\bar{\lambda} A \theta q(\theta)(E-U)$.

\section{References}

[1] Albrecht, J. and S. Vroman (2005) "Equilibrium Search with Time-Varying Unemployment Benefits", The Economic Journal 115, 631-648.

[2] Barron, J. and W. Mellow (1979) "Search effort in the labour market", Journal of Human Resources 14, 389-404.

[3] Cahuc, P. and E. Lehmann (2000) "Should Unemployment Benefits Decrease with the Unemployment Spell?", Journal of Public Economics 77, 135-153.

[4] Cahuc, P. and F. Malherbet (2004) "Unemployment Compensation Finance and Labor Rigidity", Journal of Public Economics 88, 481-501.

[5] Coles, M. and A. Masters (2004) "Duration Dependence, Unemployment Insurance Payments and Equilibrium Unemployment", Economica 71, 83-97. 
[6] Coles, M. and A. Masters (2006) "Optimal Unemployment Insurance in a Matching Equilibrium", Journal of Labor Economics 24, 109-138.

[7] Collin, C. (2000) "Les ressources des allocataires du RMI : le rôle majeur des prestations sociales", Etudes et Résultats, n 62 , DREES.

[8] Fredriksson, P. and B. Holmlund (2001) "Optimal Unemployment Insurance in Search Equilibrium", Journal of Labor Economics 19, 370-399.

[9] Hopenhayn, H. and J.P. Nicolini (1997) "Optimal Unemployment Insurance", Journal of Political Economy 105, 412-438.

[10] Hosios, A. (1990) "On the Efficiency of Matching and Related Models of Search and Unemployment", The Review of Economic Studies 57, 279-298.

[11] Jones, S. (1989) "Job search methods, intensity and effects", Oxford Bulletin of Economics and Statistics 51, 277-296.

[12] Layard, R., S. Nickell, and R. Jackman (1991) Unemployment: Macroeconomic Performance and the Labour Market, Oxford University Press.

[13] Lentz, R. (2007) "Optimal Unemployment Insurance in an Estimated job Search Model with Savings", Mimeo, University of Wisconsin-Madison.

[14] Lollivier, S. and L. Rioux (2006) "A Structural Nonstationary Model of Job Search: Stigmatization of the Unemployed by Job Offers or Wage Offers?", in Structural Models of Wage and Employment Dynamics, conference volume in honor of Dale Mortensen, edited by H. Bunzel, B. J. Christensen, G. R. Neumann, and J.-M. Robin, Elsevier, North-Holland.

[15] Mortensen, D. (1977) "Unemployment Insurance and Labor Supply Decisions", Industrial and Labor Relations Review 30, 505-517.

[16] OECD (1997) Employment Outlook, Paris, Organization for Economic Cooperation and Development.

[17] Pavoni, N. (2007) "On Optimal Unemployment Compensation", Journal of Monetary Economics, forthcoming.

[18] Pellizzari, M. (2006) "Unemployment Duration and the Interactions between Unemployment Compensation and Social Assistance", Labour Economics, vol 13, n 6, 773-798.

[19] Pissarides, C. A. (2000) Equilibrium Unemployment Theory, Second edition, MIT Press.

[20] Rioux, L. (2001a) "Recherche d'emploi et insertion professionnelle des allocataires du RMI", Economie et Statistique 346-347, 13-32.

[21] Rioux, L. (2001b) "Salaire de réserve, allocation chômage dégressive et revenu minimum d'insertion", Economie et Statistique 346-347, 137-160. 
[22] Schmitt, J. and J. Wadsworth (1993) "Unemployment benefit levels and search activity", Oxford Bulletin of Economics and Statistics 55, 1-24.

[23] Tannery, F. (1983) "Search effort and unemployment insurance reconsidered", Journal of Human Resources 18, 432-440.

[24] Wadsworth, J. (1991) "Unemployment benefits and search efforts in the UK labor market", Economica 58, 17-34.

[25] Wang, C. and S. D. Williamson (2002) "Moral Hazard, Optimal Unemployment Insurance, and Experience Rating," Journal of Monetary Economics 49, 1337-1372. 


\section{CENTRE FOR ECONOMIC PERFORMANCE Recent Discussion Papers}

845 Richard E. Baldwin Frédéric Robert-Nicoud

844 Richard B. Freeman

843 Emma Hall Carol Propper John Van Reenen

842 Fabrice Defever Farid Toubal

841 Barbara Petrongolo

840 Kevin D. Sheedy

839 Christopher A. Pissarides

838 Kevin D. Sheedy

837 Kevin D. Sheedy

836 Andrew E. Clark Ed Diener Yannis Georgellis Richard E. Lucas

835 Jean-Baptiste Michau

834 Nikolaus Wolf

833 Sharon Belenzon Tomer Berkovitz

832 Espen R. Moen Åsa Rosén

831 Eran Yashiv

830 Laura Alfaro Andrew Charlton
A Simple Model of the Juggernaut Effect of Trade Liberalisation

Labor Market Institutions Around the World

Can Pay Regulation Kill? Panel Data Evidence on the Effect of Labor Markets on Hospital Performance

Productivity and the Sourcing Modes of Multinational Firms: Evidence from French FirmLevel Data

What are the Long-Term Effects of UI? Evidence from the UK JSA Reform

Robustly Optimal Monetary Policy

The Unemployment Volatility Puzzle: Is Wage Stickiness the Answer?

Inflation Persistence when Price Stickiness Differs between Industries

Intrinsic Inflation Persistence

Lags and Leads in Life Satisfaction: A Test of the Baseline Hypothesis

Creative Destruction with On-the-Job Search

Scylla and Charybodis: the European Economy and Poland's Adherence to Gold, 1928-1936

Innovation in Business Groups

Incentives in Competitive Search Equilibrium

U.S. Labor Market Dynamics Revisited

Growth and the Quality of Foreign Direct Investment: Is All FDI Equal? 


\begin{tabular}{|c|c|c|}
\hline 829 & $\begin{array}{l}\text { Richard Layard } \\
\text { David Clark } \\
\text { Martin Knapp } \\
\text { Guy Mayraz }\end{array}$ & Cost-Benefit Analysis of Psychological Therapy \\
\hline 828 & Emma Tominey & $\begin{array}{l}\text { Maternal Smoking During Pregnancy and Early } \\
\text { Child Outcomes }\end{array}$ \\
\hline 827 & $\begin{array}{l}\text { Christos Genakos } \\
\text { Tommaso Valletti }\end{array}$ & $\begin{array}{l}\text { Testing the "Waterbed" Effect in Mobile } \\
\text { Telephony }\end{array}$ \\
\hline 826 & $\begin{array}{l}\text { Luis Garicano } \\
\text { Paul Heaton }\end{array}$ & $\begin{array}{l}\text { Information Technology, Organization, and } \\
\text { Productivity in the Public Sector: Evidence from } \\
\text { Police Departments }\end{array}$ \\
\hline 825 & $\begin{array}{l}\text { Laura Alfaro } \\
\text { Andrew Charlton }\end{array}$ & Intra-Industry Foreign Direct Investment \\
\hline 824 & $\begin{array}{l}\text { Miklós Koren } \\
\text { Silvana Tenreyro }\end{array}$ & Technological Diversification \\
\hline 823 & Régis Barnichon & $\begin{array}{l}\text { The Shimer Puzzle and the Correct Identification } \\
\text { of Productivity Shocks }\end{array}$ \\
\hline 822 & Carlos Thomas & $\begin{array}{l}\text { Search Frictions, Real Rigidities and Inflation } \\
\text { Dynamics }\end{array}$ \\
\hline 821 & $\begin{array}{l}\text { Giulia Faggio } \\
\text { Kjell G. Salvanes } \\
\text { John Van Reenen }\end{array}$ & $\begin{array}{l}\text { The Evolution of Inequality in Productivity and } \\
\text { Wages: Panel Data Evidence }\end{array}$ \\
\hline 820 & $\begin{array}{l}\text { Luis Araujo } \\
\text { Emanuel Ornelas }\end{array}$ & Trust-Based Trade \\
\hline 819 & Régis Barnichon & $\begin{array}{l}\text { Productivity, Aggregate Demand and } \\
\text { Unemployment Fluctuations }\end{array}$ \\
\hline 818 & $\begin{array}{l}\text { Rachel Griffith } \\
\text { Sokbae Lee } \\
\text { John Van Reenen }\end{array}$ & $\begin{array}{l}\text { Is Distance Dying at Last? Falling Home Bias in } \\
\text { Fixed Effects Models of Patent Citations }\end{array}$ \\
\hline 817 & $\begin{array}{l}\text { Tsutomu Miyagawa } \\
\text { YoungGak Kim }\end{array}$ & $\begin{array}{l}\text { Measuring Organization Capital in Japan: An } \\
\text { Empirical Assessment Using Firm-Level Data }\end{array}$ \\
\hline 816 & $\begin{array}{l}\text { Andreas Georgiadis } \\
\text { Alan Manning }\end{array}$ & $\begin{array}{l}\text { Spend It Like Beckham? Inequality and } \\
\text { Redistribution in the UK, 1983-2004 }\end{array}$ \\
\hline 815 & $\begin{array}{l}\text { Guy Michaels } \\
\text { Xiaojia Zhi }\end{array}$ & Freedom Fries \\
\hline 814 & Ralph Ossa & $\begin{array}{l}\text { Trade Liberalization, Outsourcing, and Firm } \\
\text { Productivity }\end{array}$ \\
\hline
\end{tabular}

